\title{
Involvement of Asian Actors in the European Commission's Online Consultations in Comparative Perspective
}

\author{
PETYA ALEXANDROVA \\ Montesquieu Institute and Leiden University \\ p.alexandrova@montesquieu-instituut.nl
}

\author{
GERT-JAN LINDEBOOM \\ Leiden University \\ gertjanlindeboom@gmail.com
}

\author{
ANNE RASMUSSEN \\ Leiden University \\ rassmussena@fsw.leidenuniv.nl
}

\begin{abstract}
In order to examine the involvement of Asian interests in European Union politics, we develop a preliminary framework for studying the involvement of external interests in EU policy -making. Using data on the online consultations of the European Commission from 2001 till 2010, we aim at explaining both the level of engagement, the types of active actors and policy areas of involvement of different regions. We find that that external representation is partly but not fully accounted for by economic ties and possession of resources. Moreover, we find variation in which areas and by which actors different regions are represented suggesting that variation in national-sectoral structures between them affects differences in the character of representation between them.
\end{abstract}

Key words: Asia, European Union, foreign interests, online consultations, interests representation, resource dependencies

\section{Introduction}

Over the last decades the European Union (EU) has been subject to both broader and deeper integration with an increasing amount of jurisdictional powers being transferred from the national level to the EU and growing power of supranational bodies and 
decision-making rules ${ }^{1}$. The process of legislation drafting in the Union is today open to a variety of interests and civil society actors, with the European Commission itself fostering a culture of consultation ${ }^{2}$. The number of interest groups active on EU level has gradually increased since the $1^{1970{ }^{3}}$. Both this systemic openness and the growing activity of the interest group population have attracted academic attention but accounts have remained limited to interests stemming from the Union itself, largely ignoring the impact of foreign interests. Relations with major trading partners such as Japan and China and new forums for cross-regional policy deliberation, such as the Asia-Europe Meeting (ASEM), have been studied primarily (if not exclusively) from an EU-centric perspective. Moreover, research on EU cooperation with non-EU countries and other regions in the world tends to concentrate on official diplomatic relations and largely ignores the role that businesses, interest groups and civil society play in this process. This article aims to address the limited knowledge of the involvement of foreign interests in EU policy making by undertaking an analysis of the involvement of Asian interests in the online consultations of the European Commission from a comparative perspective. We focus on Asia since, in recent decades, it has gained increased importance in EU trade relations and the world economy in general. To do so, we develop a framework for explaining the levels of engagement, the types of active actors and policy areas of involvement in different regions, using a dataset covering online consultations of the European Commission over the period 2001 - 2010. Online consultation is of course only one of many ways in which actors from Asian and other non-EU member states may lobby the EU. Our dataset has the advantage of covering a broad range of issues over a 10-year period. For this reason it serves as a good starting point for looking at Asian engagement, and provides a base to which future research on other types of lobbying may contribute.

Our findings reveal that external representation is partly accounted for by economic ties and possession of resources. The most active external actors come from North America, extra-EU Europe and Asia, which are also some of the regions that have the highest GDP and strongest trade ties with the EU. At the same time, we find limitations to explaining external representation based on economic resources alone. Even though Asia is the EU's leading trade partner and the region with the highest GDP in the world, Asian interests are less active than North American and European extra-EU ones. Moreover, we find that external actors focus mostly on banking and trade-related issues as well as environment and transport and that a high number of the foreign contributions come from companies, interest groups and public bodies. Variation in the national-sectoral

\footnotetext{
${ }^{1}$ T. Börzel, 'Mind the Gap! European Integration between Level and Scope', Journal of European Public Policy, Vol. 12, No. 2, 2005, pp. 217-236; L. Hooghe and G. Marks, Multi-Level Governance and European Integration, Lanham: Rowman \& Littlefield, 2001.

${ }^{2}$ European Commission, Towards a Reinforced Culture of Consultation and Dialogue - General Principles and Minimum Standards for Consultation of Interested Parties by the Commission, $\operatorname{COM}(2002) 704,2002,<$ http://eur-

lex.europa.eu/LexUriServ/LexUriServ.do?uri=COM:2002:0704:FIN:EN:PDF >, accessed 20 January, 2011.

3 J. Greenwood, Interest Representation in the European Union, New York: St Martin's Press, 2003; B. Kohler-Koch, 'Changing Patterns of Interest Intermediation in the European Union' Government and Opposition, Vol. 29, No. 2, 1994, pp. 166-180.
} 
structures of the regions helps us to explain differences in the character of representation.

The article first reviews the literature on the interactions between Asia and the EU and interest representation in the EU. The subsequent section is dedicated to outlining in more detail the Commission's consultation procedures and presenting the data and methodology of the study. Finally, our analysis will present a preliminary attempt to map the involvement of non-EU interests in online consultations over time.

\section{Contextualising the EU - Asia Relationship}

Trade relations between Asia and the EU have grown in importance over the years. Not only has the trade volume between the two regions grown significantly in the last decade4, increasing political cooperation has also manifested itself through several institutional bodies. The Asia-Europe Meeting (ASEM), founded in 1996 encapsulates this. Through this institutionalized summit European and Asian leaders come together biennially to discuss a diverse range of issues, primary with economic focus 5 . The establishment of ASEM and its subsequent summits have increasingly attracted scholarly attention in the field of EU-Asian relations. For instance, Pakpahan 6 argues that the ASEM could become a powerful institution for promoting inter-regional economic cooperation, thereby possibly reversing the global trend of creating secluded regional trade zones7. Notably however, Pakpahan's study - and in fact many other studies exploring this institutional cooperation between the EU and the ASEAN concentrate primarily on the impact of actions of the EU on Asia. ${ }^{8}$ Single case studies on the interactions between the EU and particular Asian countries or sub-regions do not broaden the picture of interest representation since such analyses are still limited to the level of the state. Recognising China's status as a global player, Fox and Godement maintain that "decisions taken in Beijing are central to virtually all the EU's pressing global concerns" and stress that Europe should pay more attention to this fact.9 Yet, it has been recognised that non-governmental organisations also play a role in the

\footnotetext{
4 M. Garcia, 'Fears and Strategies: The EU, China and Their Free Trade Agreements in East Asia' Journal of Contemporary European Research, Vol. 6, No. 4, 2010, pp. 496-513.

5 C. M. Dent, Economic Relations between the EU and East Asia: Past, Present and Future.

Intereconomics, Vol. 32, No.1, 1997, pp. 7-13.

6 B. Pakpahan, 'Contemporary Trans-regional Cooperation between Europe and Asia in a Changing World', Journal of Contemporary European Research, Vol. 6, No. 4, 2010, pp. 514-534.

7 B. Hettne and F. Söderbaum, 'Theorising the Rise of Regionness' New Political Economy, Vol. 5, No. 3, 2000, pp. 457-472.

8 D. Camroux, The Rise and Decline of the Asia-Europe Meeting (ASEM): Asymmetric Bilateralism and the Limitations of Interregionalism, 2006, Centre d'études européennes: Cahiers Européens; Dent, Economic Relations between the EU and East Asia: Past, Present and Future, op. cit.; C. M. Dent, 'The New Economic Bilateralism in Southeast Asia: Region-Convergent or Region-Divergent?' International Relations of the Asia-Pacific, Vol. 6, No. 1, 2006, pp. 81-111; A. Forster, 'The European Union in SouthEast Asia: Continuity and Change in Turbulent Times' International Affairs, Vol. 75, No. 4, 1999, pp. 743758; E. Kettunen, 2004, Regionalism and the Geography of Trade Policies in EU-ASEAN Trade, Helsinki: Helsinki School of Economics, Electronic Dissertation.

9 J. Fox and F. Godement, A Power Audit of EU-China Relations. London: European Council on Foreign Relations, 2009, <http://ecfr.eu/page/-/documents/A_Power_Audit_of_EU_China_Relations.pdf >, accessed 26 January, 2011, pp. 1.
} 
interregional relationships, for example when participating in the ASEM summits. ${ }^{10}$ Nevertheless, a high level decision-making arena, ASEM fails to reach out to the most relevant publics in Asia, and has a very low profile among business, media and civil society elites. ${ }^{11}$ Therefore, it is logical to expect that organised interests will try to promote their interests by lobbying in Brussels directly.

\section{Studying Representation of Asian Interest in the EU}

Rather than looking at the literature on high-level relations between the EU and Asia we, therefore, need to examine how external interests interact with the Union institutions in everyday politics. It is precisely in everyday politics that many of the issues of concern to Asian interests are reconciled. The literature on interest representation in the EU has suggested a prominent role for interest groups in channelling the concerns of the citizens to the formal decision-makers. ${ }^{12}$ Studies have focused mostly on particular policy areas, specific institutions or types of groups as well as interests stemming from a narrow set of EU member states. ${ }^{13}$ Besides existing studies on Japanese and Korean companies, ${ }^{14}$ there has been no specific analysis of the involvement of Asian interests in EU policy making. Representation of other extra-EU organised interests' involvement in the drafting of EU legislation has remained largely under researched.

${ }^{10}$ D. Camroux, op. cit.; Pakpahan, op. cit.

${ }^{11}$ A. Brovelli, N. Chaban, S. Lai and M. Holland, 'Invisible Forum? The Public Outreach of the Asia-

Europe Meeting (ASEM)' Journal of Contemporary European Research, Vol. 6, No. 4, 2010, pp. 535-550.

${ }_{12}$ R. Eising, 'Interest groups in EU policy-making' Living Reviews in European Governance, Vol. 3, No. 4, 2008, <http://www.livingreviews.org/lreg-2008-4>, accessed 15 January, 2011; J. Gaffney, Political Parties and the European Union, London: Routledge, 1996; E. Kirchner and K. Schwaiger, The Role of Interest Groups in the European Community, Aldershot: Gower Publishing, 1981; Kohler-Koch, op. cit.; S. Mazey and J. Richardson, (eds.), Lobbying in the European Community, Oxford: Oxford University Press, 1993.

${ }^{13}$ P. Bouwen, 'Exchanging Access Goods for Access: A Comparative Study of Business Lobbying in the European Union Institutions', European Journal of Political Research, Vol. 43, 2004a, pp. 337-369, P. Bouwen, 'The Logic of Access to the European Parliament: Business Lobbying in the Committee on Economic and Monetary Affairs', Journal of Common Market Studies, Vol. 42, No. 3, 2004b, pp. 473-95; J. Beyers, 'Gaining and Seeking Access: the European Adaptation of Domestic Interest Associations', European Journal of Political Research, Vol. 41, 2002, pp. 585-612; R. Bennet, 'The impact of European Economic Integration on Business Associations: The UK Case', West European Politics, Vol. 20, No. 3, 1997, pp. 61-90; J. Greenwood, J. Grote and C. Ronit, Organized Interests and the European Community, London: SAGE, 1992; R. Eising, The Access of Business Interests to the European Union Institutions: Notes Towards a Theory, Working Paper no 29, Oslo: Arena Centre for European Studies, 2005; R. Eising, 'Institutional Context, Organizational Resources and Strategic Choices: Explaining Interest Group Access in the European Union' European Union Politics, Vol. 8, No. 3, 2007, pp. 329-362; D. Coen, 'The Evolution of the Large Firm as a Political Actor in the European Union' Journal of European Public Policy, Vol. 4, No.1, 1997, pp. 91-108; Bennett op. cit.

14 Y. Hamada, 'The Impact of the Traditional Business-Government Relationship on the Europeanization of Japanese Firms', Journal of European Public Policy, Vol. 14, No. 3, 2007, pp. 404-421; Y. Hamada, Japanese Firms in the EU: Europeanization of Lobbying Strategies and Enduring National Characteristics, Doctoral thesis, University of London and, 2007 and C. R. Pang, 'Policy networks and multiple lobbying strategies in EU trade policy-making. A Korean perspective', Asia Europe Journal, Vol. 2, No. 3, 2004, pp. 429-444 respectively. 
The general EU interest group literature regarding what conditions the access groups enjoy in EU policy making is a departure point for an explorative study of the participation of Asian versus other interests in EU policy drafting. However, it needs to be acknowledged that this literature was developed in the study of liberal democracies. Their models of civil societies do not always appreciate the situation in Asian countries. However, some of the overarching insights from this literature are not linked to specificities of state-society structures in liberal democracies. Instead, they are formulated more generally and can be applied in other settings as well. We therefore depart from the overall findings of this literature on access to EU policy making in order to develop our framework. Eising 15 has summed up these findings by emphasizing that access (or the number of contacts interest groups have) depends on resources, political opportunities vested in the EU institutional environment and elements of organisational structure and national-sectoral embeddedness. Building upon these general ideas we suggest that four major factors influence the representation of foreign and in particular Asian organised interests in the EU: economic ties to the EU, resources, familiarity with EU practices, and fields of interregional cooperation.

The first factor - economic ties - is derived from the expectation that non-EU actors from regions that are mostly affected by EU regulation should be the ones that also have the greatest incentive to defend their interests at this policy level. So-called pluralist interest group scholars ${ }^{16}$ have, for a long time, argued that interest representation occurs in response to disturbances to the interests of a given actor. As a policy issue becomes salient and has a potential impact on the interest of certain groups in the society, those groups will mobilize and attempt to influence that policy issue. ${ }^{17}$ The stronger the economic ties between a region and the EU, the greater the likelihood that this group will have impact on EU policy making around a specific policy issue. Therefore, we assume that the stronger the economic bonds, the higher the likelihood for participation in the consultations of the Commission. To determine the economic relations of regions with the EU many different indicators could be considered. For example, we could examine whether absolute trade levels with the EU or degrees of trade interdependence between a country and the EU relative to the rest of the world play an important role. We argue in favour of using the absolute level of trade since this should act as a driver stimulating a given country to lobby the EU, irrespective of the level of trade with other countries. As long as there is something at stake, there should be a demand for lobbying activity at the EU level ${ }^{18}$ Considering the data for 2008 (table

\footnotetext{
${ }_{15}$ R. Eising, The Access of Business Interests to the European Union Institutions: Notes Towards a Theory, op. cit.

${ }^{16}$ see for example D. B. Truman, The Governmental Process: Political interests and public opinion, New

York: Knopf, 1951.

${ }^{17}$ see J. A. Caporaso, The Structure and Function of European Integration. Pacific Palisades, California: Goodyear Publishing Company, 1974; L. Cram, 'The EU Institutions and Collective Action: Constructing a European Interest' In J. Greenwood and M. Aspinwall (eds.), Collective Action in the European Union: Interests and the New Politics of Associability, London: Routledge, 1998, pp. 63-80.

${ }_{18}$ Moreover, it should be noted that in spite of our criticism we actually tried calculating the share of EU trade out of total trade for our regions. The results showed that for 2008 four of our regions (Asia, Australia and Oceania, North America and South America) had the same level of interdependence. In other words, we find no systematic variation in interdependence, which can help explain varying levels of engagement.
} 
1A), it is clear that the majority of EU foreign trade is with Asia, followed consecutively by non-EU Europe and North America. Much less trade occurs between the EU and the remaining continents. These figures suggest that we should expect Asian organised interests to be the most active ones, followed by European extra-EU ones and North American interests. We also anticipate little involvement of organised interests originating in Africa, South America or Australia.

Table 1. Trade with the EU, by region, sub-region and country (January December 2008) in bln EUR

\begin{tabular}{|l|c|c|c|c|c|c|}
\hline A & Africa & Asia & $\begin{array}{c}\text { Australia \& } \\
\text { Oceania }\end{array}$ & $\begin{array}{c}\text { Europe } \\
\text { (non-EU) }\end{array}$ & $\begin{array}{c}\text { North } \\
\text { America* }\end{array}$ & $\begin{array}{c}\text { South } \\
\text { America }\end{array}$ \\
\hline Import & 158 & 676 & 16 & 438 & 225 & 86 \\
\hline Export & 120 & 446 & 31 & 376 & 298 & 84 \\
\hline $\begin{array}{l}\text { Total amount of } \\
\text { trade (Import }+ \\
\text { Export) }\end{array}$ & 278 & 1121 & 45 & 814 & 523 & 170 \\
\hline
\end{tabular}

\begin{tabular}{|l|c|c|c|c|c|c|c|}
\hline B & $\begin{array}{c}\text { Central } \\
\text { Asia }\end{array}$ & \multicolumn{3}{|c|}{ Eastern Asia } & $\begin{array}{c}\text { Southern } \\
\text { Asia }\end{array}$ & $\begin{array}{c}\text { South- } \\
\text { Eastern } \\
\text { Asia }\end{array}$ & $\begin{array}{c}\text { Western } \\
\text { Asia }\end{array}$ \\
\hline Import & 21 & \multicolumn{2}{|c|}{399} & 57 & 79 & 120 \\
\hline Export & 7 & \multicolumn{2}{|c|}{180} & 50 & 56 & 153 \\
\hline $\begin{array}{l}\text { Total amount of } \\
\text { trade (Import + } \\
\text { Export) }\end{array}$ & 28 & \multicolumn{2}{|c|}{578} & 107 & 135 & 273 \\
\hline C & $\begin{array}{c}\text { Kazakh- } \\
\text { stan }\end{array}$ & China & $\begin{array}{c}\text { Ja- } \\
\text { pan }\end{array}$ & $\begin{array}{c}\text { South } \\
\text { Korea }\end{array}$ & India & Singe-pore & Turkey \\
\hline Import & 18 & 248 & 75 & 40 & 29 & 16 & 46 \\
\hline $\begin{array}{l}\text { Export } \\
\text { Total amount of } \\
\text { trade (Import }+ \\
\text { Export) }\end{array}$ & 24 & 326 & 117 & 65 & 61 & 38 & 110 \\
\hline
\end{tabular}

* North America includes USA, Canada and Mexico

Source: European Commission, DG Trade, <http://ec.europa.eu/trade/creating-

opportunities/bilateral-relations/statistics>, accessed 15 January, 2012.

Within Asia - the biggest trade partner region (table 1B) - we can distinguish between five geographical sub-regions. ${ }^{19}$ Half of the EU trade with this continent occurs with

19 We follow the framework of the UN for composition of geographical sub-regions within Asia. The only country we exclude here is Cyprus because even though it belongs to Western Asia, it is an EU member state since May 2004. 
Eastern Asia. The second biggest commerce partner here is Western Asia, followed by South-Eastern, Southern and only then Central Asia. Therefore, we would expect interests originating from Eastern Asia to be the most active in the consultations, followed by interests from the other four regions in the enlisted order. Table $1 \mathrm{C}$ shows the countries which contribute most to the regional trade. When applying the same logic of economic ties effect on participation of organised interests, China should be leading in interest articulation, followed by Japan and Turkey, all three countries belonging to the two biggest trading regions.

A second factor that might affect the involvement of interests from different regions is structural differences between them in terms of the resources actors possess. Interest group scholars agree that different types of resources, such as technical expertise, policy information, budget and the economic clout of the organizations help groups gain access. $^{20}$ Whereas studies have typically measured the resources of particular organizations, it is harder to assess the general strength of interests in terms of resources on the macro level. All things being equal, actors from a relatively wealthy region are more likely to have a higher command of resources to defend their interests at the EU scene than actors from a relatively poor, developing region.

A very crude measure of organizational strength is the economic prosperity of a region, estimated via Gross Domestic Product (GDP). This leaves out cultural, political and other societal differences between countries, which also remain relevant for variation in levels of participation in EU lobbying. Ideally additional factors, such as the development of civil society, political culture, the quality of the educational system, the number of companies who could lobby would be considered. However, for some of these variables, such as the development of civil society, systematic, comparable data simply does not exist on a cross-country basis. For others, some indicators exist. For example, we could have used the human development index, which takes education, living standards and health, or we could have consulted the World Bank list of registered companies in different countries. We have compiled this data, but presenting it here would not have altered our findings, since these measures are highly correlated. Finally, as we show later, nearly all Asian interests that mobilize in European consultations are either companies or business associations. It is exactly these types of groups that make up the gross domestic product. Therefore, GDP can be used as a reliable indicator of the resource potential of actors from a given economy to act vis-à-vis the EU.

Table 2A shows that Asia is the region with highest GDP in the world, followed closely by North America. Other regions - South America, extra-EU Europe, Africa and Australia - have a much lower level of GDP. Thus, linking this factor with the previously formulated economic ties, Asia still remains the region which we could expect to articulate its interests most strongly. Unlike our economic ties indicator, however, GDP

${ }^{20}$ Mazey and Richardson, op. cit.; R. Eising, 'Institutional Context, Organizational Resources and Strategic Choices: Explaining Interest Group Access in the European Union’, op. cit. 
size predicts higher involvement of North American than European non-EU interests. The rest of the world is still expected to be less active. ${ }^{21}$

Table 2. GDP at current prices (2009) in bln US Dollars

\begin{tabular}{|l|c|c|c|c|c|c|}
\hline A & Africa & Asia & $\begin{array}{c}\text { Australia and } \\
\text { New Zealand }\end{array}$ & $\begin{array}{c}\text { Europe } \\
\text { (non-EU) }\end{array}$ & $\begin{array}{c}\text { Northern } \\
\text { America }\end{array}$ & $\begin{array}{c}\text { South } \\
\text { America }\end{array}$ \\
\hline GDP & 1.425 & 6 & 1.131 & 2.431 & 15.463 & 3.861 \\
\hline
\end{tabular}

\begin{tabular}{|l|c|c|c|c|c|c|c|}
\hline B & $\begin{array}{c}\text { Central } \\
\text { Asia }\end{array}$ & \multicolumn{2}{|c|}{ Eastern Asia } & $\begin{array}{c}\text { Southern } \\
\text { Asia }\end{array}$ & $\begin{array}{c}\text { South- } \\
\text { Eastern Asia }\end{array}$ & $\begin{array}{c}\text { West- } \\
\text { ern Asia }\end{array}$ \\
\hline GDP & 169 & \multicolumn{2}{|c|}{11.134} & 1.968 & 1.473 & 1.942 \\
\hline C & $\begin{array}{c}\text { Kazakh- } \\
\text { stan }\end{array}$ & China & Japan & $\begin{array}{c}\text { South } \\
\text { Korea }\end{array}$ & India & Indonesia & Turkey \\
\hline GDP* & 109 & 4.984 & 5.069 & 833 & 1.287 & 540 & 615 \\
\hline
\end{tabular}

Source: United Nations, National Accounts Main Aggregates Database, $<$ http://unstats.un.org/unsd/snaama/Introduction.asp>, accessed 15 January, 2012.

The ordering of Asian sub-regions (table 2B) also gives almost similar results as 'trade with the EU,' our previous indicator; only Southern and Western Asia are much closer now. Therefore, we could still expect Eastern Asia to be the most active part of the continent, Central Asia the least active one, while for the rest the level of interest group activity should be similar. Looking further within Asia (table $2 \mathrm{C}$ ), similar countries appear to be important in our assumed relationship between interest representation and resources as in the one focusing on economic ties. Nevertheless, the order is different and if GDP determines the level of involvement of organised interests, we could expect Japan and China to be most active, followed by India, Russia, South Korea, Turkey and Indonesia on a much lower level.

A third factor which might have some impact is familiarity with the consultation procedure. Socialisation with a particular practice involves both policy learning and adaptation, implying that 'an agent switches from following the logic of consequences to a logic of appropriateness' 22 . In other words, it can be expected that organised interests, which have already become familiar with the process of presenting their interests, are more likely to be involved again. The more familiar an actor becomes with the

${ }^{21}$ The ordering of the regions hardly changes if instead of GDP, we use Gross National Income (GNI), only the numbers of non-EU Europe and South America become almost the same.

${ }_{22}$ J. T. Checkel, 'International Institutions and Socialization in Europe: Introduction and Framework' International Organization, Vol. 59, No. 4, 2005, pp. 801-826 (p. 804). 
procedural features of an institutionalised system of interest articulation, the easier it becomes to express an opinion. Hence, we expect that in all regions the participation in online consultations should increase progressively the longer an actor has engaged with it.

A fourth factor is the national-sectoral structure of the region. The areas a region is going to pursue and the types of actors involved will depend on the type of interests and strong economic sectors that exist in the countries of the region. It is not easy to collect such data on a global basis. Therefore, we have examined whether there is a link between the fields in which cooperation between the EU and the region in question takes place and looked at the policy areas in which interest representation occurs. The EU-Asia Strategic Framework for Enhanced Partnerships from 2001 focuses primarily on issues of security, trade and investment, development, democracy and the rule of law and environment. ${ }^{23}$ Similar fields tend to be present in the New Transatlantic Agenda with the US, which has been active since $1995 .{ }^{24}$ In the European non-EU region the diversity of cooperation in terms of policy fields is extremely high. Nevertheless, when cooperation with the important partners from the European Economic Area is considered, strong economic, security, and immigration components can be identified. ${ }^{25}$ Thus, following the assumption that cooperation in a particular policy field triggers interest mobilisation in this field we could expect that trade-and finance-related interests should be highly represented in the Commission consultations for all regions, whereas there should be diversity of representation in other policy fields. Finally, the level of activity per policy field could be used as an indirect predictor for the types of actors that we would expect to be active. Hence, to some extent there might be a linkage between an activity in different policy areas and the type of actors that mobilize. If a country is very active in foreign policy, public actors might play a prominent role, whereas in other types of policies other interests might dominate. Specifically, we hypothesize that if trade and finance are attracting participation, then companies and specific interest groups could be expected to be contributing most. Before examining the validity of these expectations, we first present our data and methodology.

${ }^{23}$ European Commission, Europe and Asia: A Strategic Framework for Enhanced Partnerships, $\operatorname{COM}(2001) 469$ final, 2001

$<$ http://ec.europa.eu/development/icenter/repository/strategy_asia_2001_en.pdf>, accessed January 26, 2011.

24 European Commission, New Transatlantic Agenda, 1995,

<http://www.eeas.europa.eu/us/docs/new_transatlantic_agenda_en.pdf>, accessed 26 January, 2011.

25 European Free Trade Association, European Economic Area Agreement, 1994,

<http://www.efta.int/legal-texts/EEA/main-text-of-the-agreement.aspx>, accessed 26 January, 2011;

European Economic Community, Agreement between the European Economic Community and the Swiss Confederation, 1972, <http://eur-

lex.europa.eu/LexUriServ/LexUriServ.do?uri=CELEX:21972Ao722\%2803\%29:EN:HTML>, accessed 26 January, 2011. 


\section{Data and Method}

European Commission consultations are one of the most well-established ways for influencing policy documents under preparation. They help the Commission to acquire legitimacy by including the voice of civil society and gain expertise thereby ensuring the quality of legislation. Consultations can involve all types of societal actors, ranging from local governmental bodies to individual citizens and experts. Any initiative that is subject to an extended impact assessment is generally open for consultation. ${ }^{26}$ Consultations can range from forums or conferences, organised for all interested parties or restricted to particular expert groups to online calls to send an opinion regarding a proposal. The last - online consultations - are open to any group, organisation or individual, including foreign actors, and represent a much cheaper and more accessible tool for influencing legislation drafting. ${ }^{27}$ Calls for such consultations are posted on most Commission Directorates' (DGs) webpages and generally on the Your Voice in Europe website.

In this article we have used a new dataset on the online consultations from 2001 to 2010, including information about the policy issues on which consultation took place and the actors who participated. Policy areas have been coded following the EU codebook of the Comparative Policy Agendas Project 28 - an EU version of an internationally standardised codebook originating from Baumgartner and Jones' agenda-setting project. ${ }^{29}$ Types of actors have been classified in several broad categories, namely companies, public bodies, European institutions, private persons, interest groups and international organisations. Altogether the dataset includes information about 170 consultations in which foreign actors participated with a total of 877 contributions. ${ }^{30}$

Since so little is known about the participation of non-EU interests in EU policy drafting, our analysis in this article will remain largely descriptive. We rely mostly on crosstabs for assessing whether the four factors identified in the previous section affect foreign representation in the online consultations. However, we will also use the MannWhitney's U statistic to determine whether different samples of data shown in our crosstabs significantly deviate from each other. It is similar to a standard t-test but more appropriate here since the data is not measured at an interval level and also not necessarily normally distributed.

${ }^{26}$ European Commission, Towards a Reinforced Culture of Consultation and Dialogue - General Principles and Minimum Standards for Consultation of Interested Parties by the Commission, op. cit. ${ }_{27}$ C. Quittkat and B. Finke, 2008, 'The EU Commission Consultation Regime', in B. Kohler-Koch, D. De Bièvre and W. Maloney (eds.), Opening EU-Governance to Civil Society. Gains and Challenges. CONNEX Report Series No o5, Mannheim: CONNEX - Network of Excellence, pp.183-222.

${ }^{28}$ P. Alexandrova, G. Breeman, S. Brouard, M. Carammia, S. Princen, A. Rasmussen and A. Timmermans, European Union Agendas Project Codebook, Version 2.0, December 2010.

${ }^{29}$ See < http://www.policyagendas.org/>, accessed 15 January, 2012 and

<http://www.comparativeagendas.org/>, accessed 15 January, 2012.

$3^{30}$ The overall dataset is bigger and includes contributions stemming from the EU as well as truly

international ones. However, those are not relevant for the present analysis. 


\section{Asian Organised Interests in a Comparative Perspective}

\section{Regions and States in EU Policy Preparation}

As a first exploration of the data, we assessed the nationality of all actors that were involved in the online consultations grouped by continent, as displayed by table 3A. If we look at the interests that contributed, neither our prediction based on economic ties between regions, nor the one based on GDP is confirmed. We find a relatively equal number of actors from North America (especially USA) and European non-EU countries (predominantly Norway and Switzerland). Actors from Asia also seek representation at the Commission but in considerably smaller numbers than North America and extra-EU Europe.

Table 3. Foreign and Asian contributions to online consultations

\begin{tabular}{|l|c|c|}
\hline $\begin{array}{l}\text { Consultation } \\
\text { Contributions }\end{array}$ & Nr. & Percent \\
\hline Africa & 16 & $1,82 \%$ \\
\hline Asia & 151 & $17,22 \%$ \\
\hline $\begin{array}{l}\text { Australia and } \\
\text { Oceania }\end{array}$ & 16 & $1,82 \%$ \\
\hline Europe (Non-EU) & 267 & $30,44 \%$ \\
\hline North America & 418 & $47,66 \%$ \\
\hline South America & 9 & $1,03 \%$ \\
\hline Total & 877 & $100 \%$ \\
\hline
\end{tabular}

\begin{tabular}{|r|c|c|}
\hline $\begin{array}{l}\text { Consultation } \\
\text { Contributions }\end{array}$ & Nr. & Percent \\
\hline Central Asia & \multicolumn{1}{|c|}{1} & $0,66 \%$ \\
\hline Eastern Asia & 93 & $61,59 \%$ \\
\hline China & 63 & $42 \%$ \\
\hline South Korea & 12 & $12 \%$ \\
\hline India & 8 & $5 \%$ \\
\hline Southern Asia & 12 & $7,95 \%$ \\
\hline South-Eastern Asia & 10 & $6,62 \%$ \\
\hline Western Asia & 35 & $23,18 \%$ \\
\hline Turkey & 19 & $13 \%$ \\
\hline Israel & 6 & $4 \%$ \\
\hline Total & 151 & $100 \%$ \\
\hline
\end{tabular}

When we look at the Asian sub-regions, we note that most contributions come from Eastern Asia as suggested by the economic ties expectation. Also in line with this expectation, a significant degree of participation of Western Asian actors exists and much less from Southern, Central and South-Eastern Asia. The involvement of the most active region is due to contributions from three states only: Japan, China and South Korea (table 3B). These are the three Eastern Asian states with the greatest amount of trade amount with the EU. In the second most active region Turkish actors make up for more than half of the contributions, while others are coming from a number of other countries. In Southern Asia, India is the leading participant, whereas in South-Eastern Asia, activity is spread in small portions across five countries. Thus, our expectation that 
economic ties influence interest activity per region and state in Asia is very much supported. The sub-regions and countries with the highest trade amount with the EU are indeed the most involved in the Commission's consultations.

Our GDP prediction confirms Eastern Asia as the most active sub-region on the continent. The level of participation for all regions corresponds to the ordering in terms of GDP. On the country level, Japan is confirmed as the most active Asian state when it comes to interest articulation. The same applies generally when considering the other countries leading in terms of GDP like China, India, South Korea and Turkey.

We have already indicated that the expectations based on economic-ties and resources alone are not sufficient to explain the level of participation in the European Commission's online consultations. Other factors undoubtedly play a role in triggering interest involvement. Nevertheless, as expected, Africa, South America and Australia are not very active in trying to push for their interests on EU level. Moreover, the analysis on sub-regional and state level within Asia is to a great extent explained by economic ties and GDP. Therefore, even though these arguments do not seem to hold completely true in all cases, they should definitely not be rejected. Indeed regions with strong trade relationships with the EU and higher GDP levels are more prone to articulate their preferences in the phase of policy drafting. However, trade and resources are not the only indicators and when comparing the most active regions a more refined explanation should also be sought.

\section{Longitudinal Patterns of Interest Representation}

Figure 1 displays the contributions to consultations per year by the actors in each region. Looking at the table bars, we see that the expected rising trend in contributions is generally not confirmed for non-EU Europe, North America and Asia, whereas for the other continents the numbers are too small to speak of trends. The lower numbers for all continents in 2010 are due to the incomplete data for this year and should not be interpreted as a drop of the number of contributions. ${ }^{1}$ The total number of consultations which received responses by foreign actors increased over the years, as did the number of consultations issued by the Commission. To determine the extent to which the rising number of foreign contribution is a simple reflection of the higher number of consultations per year or indeed results from an increased likelihood that foreign actors participate in consultations a control is needed. To achieve this, we divide the total number of foreign contributions in a given year by the number of consultations (line in figure 1 with scale on the right-hand-side y-axis). This graph shows some fluctuations between the individual years, but it is hard to draw straightforward conclusions regarding whether familiarity with the procedures contributes to an increased involvement of non-EU interests. It is notable that the most active regions - North America, extra-EU Europe and Asia - show different trends over time. Asia, in particular, had its peak in 2004, dropped in participation in 2005 and since then has slightly been increasing. Hence, it does not seem likely that familiarity with the procedure has a positive effect on the rising number of contributions in each region. Additional explanations have to be sought in order to make sense of the specific trends

${ }^{31}$ The year 2001 is not shown in the figure because it contains only one contribution. 
over time. The exact topics on which the Commission launches consultations for example might be a better predictor of the foreign response rate. We turn to this idea in the following section.

\section{Figure 1. Number of contributions per year}

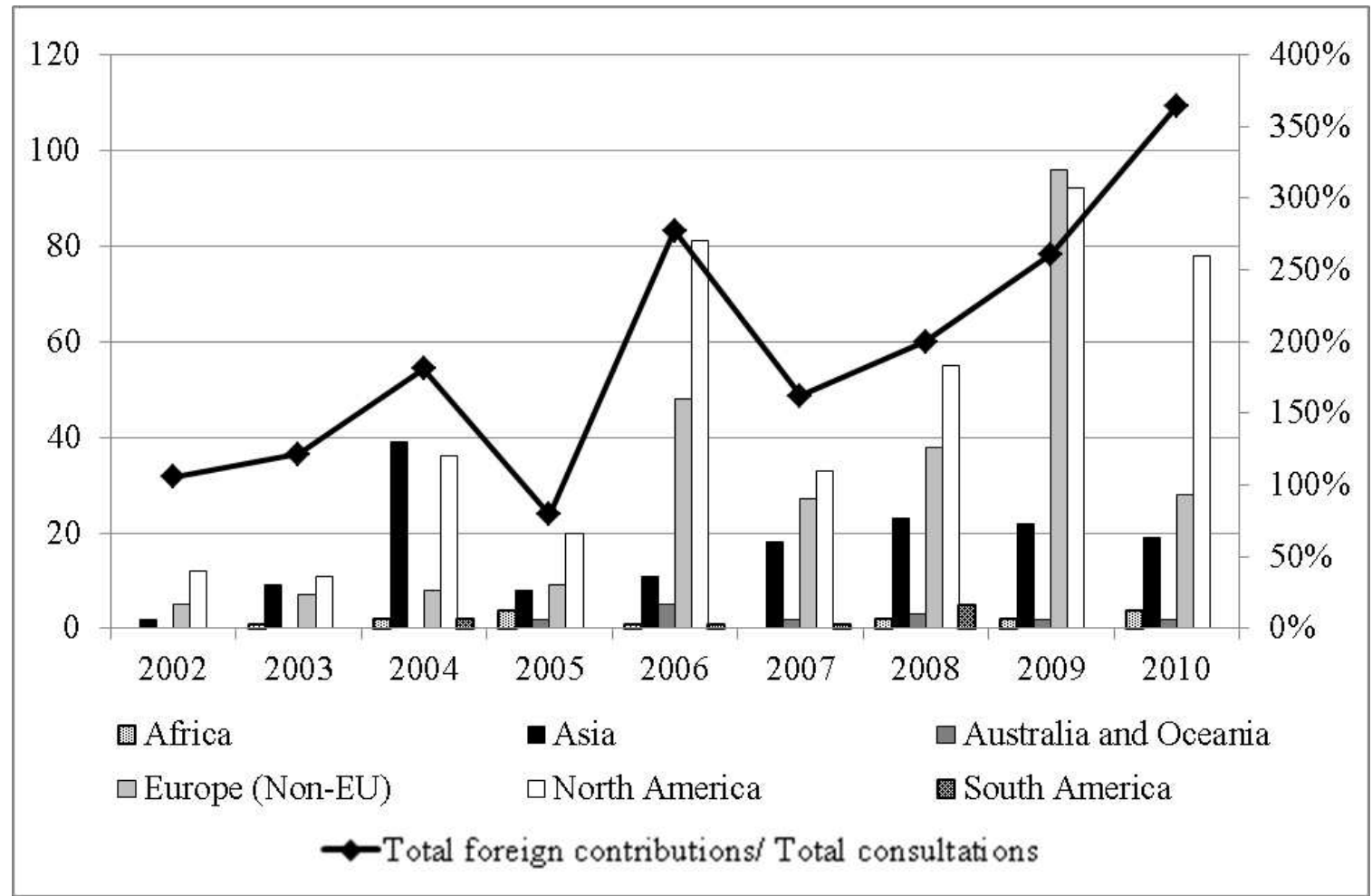

\section{Organised Interests across Policy Fields}

We now focus on different policy areas that attract participation of interests outside the EU, as displayed in Table 4. Note that, although all consultations were coded according to the 21 categories, as explained above, we present only those policy areas with a sufficient number of active actors. $3^{2}$ As table 4 suggests our expectation that financeand trade-related policies should attract most contributions holds true only for non-EU Europe and North America. These fields play a role but do not dominate activity in all regions, and in particular for Asia. In terms of policy field of involvement Asia differs significantly from both North America and non-EU Europe $(\mathrm{p}<.05)$. While North American and non-EU European interests seem to prioritise issues of banking and financial regulation, Asian actors primarily focus on the environment. Surprisingly, it is exactly on environmental issues and transport where Asia scores high in terms of participation in the consultations. This interest mobilization is however surprising only at a first glance. The prominence of transport may be explained by the role of commerce between Asian countries and the EU, since the essential role of transport in the

32 Only policy fields accounting for more than approximately 10\% for Asia are presented. 
continuation and development of trade between Europe and Asia' has been underlined in the Strategic Framework for cooperation between the two regions. 33 Environmental challenges which the EU has to tackle together with its partner Asia are also strongly emphasised in this document. 34 Finally, science and technology play a role in almost all the regions, and scores third when it comes to looking at participation of Asian interests specifically.

A good example of Asian contributions appears the 2005 consultation on the types of hazardous substances that should no longer be used in electronic equipment. This consultation by Directorate-General Environment is conducted on a regular basis in order to allow scientific progress to inform decision-making. As a major producer of electronic equipment, many Asian companies had considerable interests to transmit to the European policy makers. The Directive on hazardous substances, which is often revised on the basis of these consultations, has immediate effects for the position of electronic equipment exporting countries in Asia. Another telling example is the 2004 consultation on the revision of Commission Regulation on exemptions from the common market competition rules for certain categories of agreements between undertakings in the air transport industry. Half of the foreign contributions sent in this online consultation process came from Asian actors.

Table 4. Contributions per policy area (by continent)

\begin{tabular}{|l|c||c||c|c|c|c|c|}
\hline & Africa & Asia & $\begin{array}{c}\text { Australia } \\
\text { and } \\
\text { Oceania }\end{array}$ & $\begin{array}{c}\text { Europe } \\
\text { (Non-EU) }\end{array}$ & $\begin{array}{c}\text { North } \\
\text { America }\end{array}$ & $\begin{array}{c}\text { South } \\
\text { America }\end{array}$ & Total \\
\hline $\begin{array}{l}\text { Banking and } \\
\text { finance }\end{array}$ & $6,25 \%$ & $9,27 \%$ & $12,50 \%$ & $34,08 \%$ & $33,25 \%$ & $11,11 \%$ & $28,28 \%$ \\
\hline Transportation & $18,75 \%$ & $17,22 \%$ & $25,00 \%$ & $14,23 \%$ & $11,00 \%$ & $0,00 \%$ & $13,34 \%$ \\
\hline Environment & $18,75 \%$ & $47,68 \%$ & $37,50 \%$ & $15,73 \%$ & $32,30 \%$ & $22,22 \%$ & $29,65 \%$ \\
\hline $\begin{array}{l}\text { Science and } \\
\text { technology }\end{array}$ & $0,00 \%$ & $9,93 \%$ & $12,50 \%$ & $6,37 \%$ & $7,66 \%$ & $11,11 \%$ & $7,64 \%$ \\
\hline Foreign trade & $12,50 \%$ & $6,62 \%$ & $0,00 \%$ & $1,12 \%$ & $1,20 \%$ & $22,22 \%$ & $2,51 \%$ \\
\hline Other & $43,75 \%$ & $9,27 \%$ & $12,50 \%$ & $28,46 \%$ & $14,59 \%$ & $33,33 \%$ & $18,59 \%$ \\
\hline Total \% & $100 \%$ & $100 \%$ & $100 \%$ & $100 \%$ & $100 \%$ & $100 \%$ & $100 \%$ \\
\hline Total Nr. & 16 & 151 & 16 & 267 & 418 & 9 & 877 \\
\hline
\end{tabular}

Types of Actors Involved in EU Consultations

We now turn to considering the differences in types of actors as presented in Table 5 . The U statistic shows significant differences in actor types between North America and Asia $(\mathrm{p}<.01)$, whereas non-EU Europe and Asia do not differ significantly. Table 5 shows

33 European Commission, Europe and Asia: A Strategic Framework for Enhanced Partnerships, op. cit. 34 Ibid. 
that companies represent more than half of the North American actors, some forty per cent of the group of Asian interests and only one fourth of the European non-EU actors. A closer look at our data reveals that individual companies from all four Asian regions contributed substantially to the consultations.

Table 5. Contributions per types of actors

\begin{tabular}{|c|c|c|c|c|c|c|c|}
\hline & Africa & Asia & $\begin{array}{l}\text { Aust- } \\
\text { ralia and } \\
\text { Oceania }\end{array}$ & $\begin{array}{c}\text { Europe } \\
\text { (Non- } \\
\text { EU) }\end{array}$ & $\begin{array}{c}\text { North } \\
\text { America }\end{array}$ & $\begin{array}{c}\text { South } \\
\text { America }\end{array}$ & Total \\
\hline $\begin{array}{l}\text { Company } \\
\text { Public } \\
\text { Private } \\
\text { person } \\
\text { Interest } \\
\text { group } \\
\text { Other or } \\
\text { unknown } \\
\end{array}$ & $\begin{array}{r}56,25 \% \\
18,75 \% \\
0,00 \% \\
18,75 \% \\
6,25 \% \\
\end{array}$ & $\begin{array}{c}41,72 \% \\
22,52 \% \\
3,97 \% \\
30,46 \% \\
1,32 \% \\
\end{array}$ & $\begin{array}{c}43,75 \% \\
31,25 \% \\
6,25 \% \\
18,75 \% \\
0,00 \% \\
\end{array}$ & $\begin{array}{c}26,97 \% \\
48,31 \% \\
4,49 \% \\
19,48 \% \\
0,75 \% \\
\end{array}$ & $\begin{array}{c}69,62 \% \\
4,07 \% \\
5,74 \% \\
19,86 \% \\
0,72 \% \\
\end{array}$ & $\begin{array}{l}22,22 \% \\
66,67 \% \\
11,11 \% \\
0,00 \% \\
0,00 \% \\
\end{array}$ & $\begin{array}{r}50,63 \% \\
22,12 \% \\
5,02 \% \\
21,32 \% \\
0,91 \% \\
\end{array}$ \\
\hline Total \% & $100 \%$ & $100 \%$ & $100 \%$ & $100 \%$ & $100 \%$ & $100 \%$ & $100 \%$ \\
\hline Total Nr. & 16 & 151 & 16 & 267 & 418 & 9 & 877 \\
\hline
\end{tabular}

The high number of public actors in some regions, including Asia, warrants more attention. We would expect such a pattern for European actors, where the literature points to a high involvement of public actors, given that many local or regional governments play an active role in the EU policy-making scene. 35 Yet, it is less clear to what extent this pattern should be present outside the Union. The non-significant result of the Mann-Whitney test comparing Asia to extra-EU Europe suggests there might be similarities of representation between these regions. A closer look at the data reveals that a high number of Asian public actors belongs to Western Asia. Within this subregion, more than half of the contributions come from Turkey, and the actors involved range from trade to human rights ministries, even including the office of the prime minister. Turkey's pending EU membership application is probably important here and may help to explain the high number of state actors that are active. Turkey has elaborate cooperation with the EU in a number of areas. The high number of public contributions from non-EU Europe is likely to be an artefact of the close cooperation of these countries with the EU within the framework of the European Economic Area.

In Asia, specific interest groups also tend to be a major group seeking representation. In fact, interest groups are more strongly represented here than in all other regions except for North America. These come predominantly from Eastern Asia, in particular Japan

35 M. Tatham, With, Without or Against You? The Interest Representation of States and their Sub-State Entities in the European Union, PhD Dissertation, European University Institute, Florence, 2010. 
and partially South Korea. Just like the companies from these countries, interest groups are active on issues of environment and transportation, and to a lesser extent on financial issues. This is not surprising, given that almost all Asian interest groups are trade or business related.

\section{Conclusion}

So far, EU-Asian relations have been examined predominantly from an EU-centric perspective, neglecting the involvement of Asian interests in day-to-day EU policy making. This paper has presented an analysis of the representation of Asia in the European Commission's online consultations in comparative perspective. We derived a preliminary framework for examining the involvement of external interests in order to understand the level of engagement, the types of active actors and policy areas of involvement of different regions. Overall, we see that the strongest predictor of participation in EU consultation is the degree of trade links with the EU and the absolute resource levels of the countries involved. We also find evidence that differences in national-sectoral structures play a role even if here the support for our expectations is less clear-cut.

More specifically, although Asia is the EU's leading trade partner and the region with highest GDP in the world, it is not as active as North American and extra-EU European interests. Yet, the sub-regions and states within Asia which are trading mostly with the EU and in possession of the highest GDP level are also the ones that are contributing mostly. Furthermore, we do not find evidence of increased participation in online consultations over time due to increasing familiarity with EU practices. Instead, participation rates fluctuate and vary between the five regions. In contrast, we find some support for our fourth expectation that differences in national-sectoral structures between regions may affect the character of interest representation. While banking, finance and trade issue appear to matter in all regions, their importance differs. As a whole, a relatively diverse range of policy fields attracts participation in the different regions. In Asia, for example, transport and environment have received a high degree of attention. When it comes to looking at types of actors, we see that in Asia, just like in North America and Africa, private companies are the most active actors. However, in other regions this picture is different and high participation of public bodies from a few particular countries both in Asia and in some other regions can be seen. As expected, Asia is also unique in its high relative share of business-related interest groups.

Overall, our framework proved useful in understanding the levels of engagement of Asian interests in EU consultations. Future research should expand this in two ways. First, additional factors that may impact the level of participation should be considered. We have already pointed to factors such as political culture, development of civil society, level of state versus private ownership and human rights. However, data gathering on this point is, as we already emphasised, far from easy. Despite such measurement problems, however, we believe that such an exercise would be worthwhile as it might help us account for some of the unexplained variation discussed in this article. Second, 
future studies should expand on our research by looking at the involvement of Asian actors in types of EU policy making beyond online consultations. As already mentioned, consultations are only one type of engagement. To get a complete picture we would therefore need to compare it with other types of participation, such as informal lobbying of the EU institutions or participation in expert committees. In doing this our framework could be tested in a much broader range of settings than was possible with the online consultations, and we could further increase our understanding of the behaviour of non-EU interest groups in the policy drafting in Brussels. 